\title{
A DITADURA CIVIL-MILITAR NO ROMANCE K. RELATO DE UMA BUSCA, DE BERNARDO KUCINSKI
}

\section{THE CIVIL-MILITARY DICTATORSHIP IN K. RELATO DE UMA BUSCA, A NOVEL BY BERNARDO KUCINSKI}

DOI 10.20873/uft2179-3948.2021v12n2p10-28

\section{Rafael Nunes Ferreira ${ }^{1}$}

Resumo: O presente estudo apresenta uma leitura da obra K. Relato de uma busca (2011), de Bernardo Kucinski, narrativa testemunhal em que o escritor aborda, ficcionalmente, o episódio histórico envolvendo o desaparecimento de sua irmã e de seu cunhado durante a ditadura civilmilitar (1964-1985). Parte-se da premissa de que a literatura testemunhal desempenha um papel crucial para a compreensão da história do século XX e, por conseguinte, da produção estética desse período.

Palavras-chave: literatura brasileira contemporânea; ditadura; Bernardo Kucinski.

Abstract: This study presents a reading of the work K. Relato de uma busca (2011), written by Bernardo Kucinski, a testimonial narrative in which the writer, in a fictional way, approaches the historical event involving the disappearance of his sister and brother-in-law during the civilmilitary dictatorship (1964-1985). In this sense, it is based on the premise that the testimonial literature plays a crucial role for understanding the XX century history and, consequently, the aesthetics production of this period.

Keywords: contemporary brazilian literature; dictatorship; Bernardo Kucinski.

\section{Introdução}

1964 se inscreveu na História como o ano em que um movimento de oficiais das Forças Armadas pôs fim ao governo de João Goulart, dando início ao período de 21 anos em que militares, apoiados por lideranças civis, comandaram os destinos da nação. O debate sobre esse período insere-se no contexto político de luta pelo direito à memória, à verdade e à justiça para as vítimas da ditadura civil-militar (1964-1985). Sobre esse aspecto, José Carlos Moreira da

\footnotetext{
${ }^{1}$ Mestre em Letras, Área de Concentração Estudos de Literatura, pelo Programa de Pós-Graduação em Letras da Universidade Federal do Rio Grande do Sul (UFRGS). Técnico-Administrativo em Educação (TAE) na Universidade Federal do Pampa (UNIPAMPA). ORCID: https://orcid.org/0000-0002-0715-960X Endereço eletrônico: raffael_05@yahoo.com.br
} 
Silva Filho (2009, p. 128) afirma: “A batalha hermenêutica pela significação do passado é algo visível no contexto político brasileiro. Em especial com relação aos episódios vivenciados durante a ditadura militar". Trata-se de um empreendimento que visa a combater os mecanismos de esquecimento e de silenciamento que foram impostos antes mesmo do término da ditadura.

Toda memória, de acordo com Márcio Seligmann-Silva (2012, p. 64), nasce como resultado de "conflitos e negociações que se iniciam dentro das pessoas que vivenciaram aquele evento e depois se desdobram nas relações entre os indivíduos, grupos e classes, que se embatem na esfera pública". Significa dizer também que não existe apenas "uma memória" sobre o período da ditadura. Ao invés disso, deve-se falar em memórias variadas e conflitantes. Contudo, o estudo da história das representações de dado contexto histórico tenta, como parte de seu desafio, "estabelecer certas linhas de forças predominantes". Sobre a ditadura brasileira, Seligmann-Silva (2012, p. 64) questiona:

\begin{abstract}
Devemos nos perguntar se no embate entre as diversas memórias daquele período predominaria a versão dos que preferem "virar a página" e enterrar a memória impedindo também todo e qualquer enfrentamento jurídico e testemunhal daquele tempo —, ou se dominaria hoje no Brasil uma cultura da memória, que inclui a produção de livros com testemunhos, a construção de memoriais, homenagens aos mortos do conflito, uma recepção expressiva da produção cultural da época, seja ela literária, musical ou cinematográfica.
\end{abstract}

A resposta, para o autor, parece clara: predomina na cultura brasileira a corrente daqueles que tentam apagar do passado os crimes praticados pelo governo brasileiro durante a ditadura. Um exemplo disto é a Lei da Anistia, de 1979. Em seu texto, foi utilizada a denominação "ausentes" para se referir aos desaparecidos pela ditadura, o que, segundo Silva Filho (2009, p. 129), "leva à conotação de uma morte presumida e não de um assassinato cujo cadáver não é encontrado".

A tarefa da rememoração dos anos de chumbo localiza-se num campo da política da memória e da História repleto de tensões. Para Seligmann-Silva (2013, p. 64, grifos do autor), "pode-se falar em uma ética da representação do passado que implica a nossa dívida para com ele e para com os mortos". A Lei de Anistia permitiu que torturadores permanecessem impunes pelos crimes que cometeram, uma situação que contou com a cumplicidade do poder judiciário. Muitos destes "não apenas preferem esquecer essa história, apagá-la da memória e da história, como também [...] se orgulham de ter torturado com técnicas que não deixaram marcas nos corpos das vítimas" (SELIGMANN-SILVA, 2013, p. 85, grifos do autor). Além disso, como observa Maria Lygia Quartim de Moraes (2008, p. 15), "uma das mais cruéis práticas das ditaduras latino-americanas foi a de 'matar a morte', sumindo com os corpos dos opositores 
políticos presos, torturados e assassinados". O efeito devastador desta tentativa de "memoricídio consistia não só em eliminar a prova por excelência da cena do crime — os corpos das vítimas -, mas também em extinguir, por completo, as existências e as memórias de pessoas condenadas à morte pela política dos quartéis.

Por outro lado, ao longo desses anos, houve várias ações (individuais e coletivas) que visaram ao resgate da memória política do país, tais como: a atuação de familiares de mortos e desaparecidos e de entidades de Direitos Humanos; as ações promovidas por organizações como a Ordem dos Advogados do Brasil; os trabalhos desenvolvidos, em caráter institucional, nas esferas de governo Municipal, Estadual e Federal; o aumento de estudos e pesquisas acadêmicas relacionadas à história e à memória da ditadura, bem como a difusão de obras (livros, diários, depoimentos, filmes, documentários etc.) que trazem à discussão essa temática, dentre outras. Sobre essa questão, Eurídice Figueiredo (2017, p. 15) aponta dois momentos decisivos, quer para a apuração das graves violações aos direitos humanos, quer para o arquivamento de documentos comprobatórios das acusações. De acordo com a autora: “[...] por iniciativa da sociedade civil, houve o trabalho feito pelo grupo "Brasil: nunca mais", [...] por ação governamental, a Comissão Especial sobre Mortos e Desaparecidos e a Comissão Nacional da Verdade" (FIGUEIREDO, 2017, p. 15).

É nesse contexto de forte polarização que o presente trabalho busca analisar o romance K. Relato de uma busca, de Bernardo Kucinski, publicada em 2011. Trata-se de uma obra da Literatura Brasileira contemporânea fortemente calcada em uma experiência ao mesmo tempo individual e coletiva. No romance, Kucinski aborda, pela via ficcional, o episódio histórico envolvendo o desaparecimento de sua irmã, Ana Rosa Kucinski, e de seu cunhado, Wilson Silva, durante a ditadura civil-militar (1964-1985). Ambos eram militantes da Ação Libertadora Nacional (ALN) e morreram em circunstâncias até hoje não esclarecidas por completo, como será tratado a seguir.

\section{Ana Rosa Kucinski e Wilson Silva}

Ana Rosa Kucinski Silva nasceu em 12 de janeiro de 1942, na cidade de São Paulo. Era professora no Instituto de Química na Universidade de São Paulo (USP). Wilson Silva nasceu em 21 de abril de 1942. Físico formado pela USP, com especialização em Processamentos de Dados, trabalhava na empresa SERVIX/SP. O desaparecimento de Ana Rosa e Wilson Silva situa-se no contexto de ferocidade da política do aparato repressivo, que tinha, na ordem do dia, 
o extermínio dos seus opositores: "Matem os terroristas, matem os carteiros que entregam suas cartas. Os familiares, os amigos, seja o que for. Só não quero que morra nenhum de vocês"2. Sobre o desaparecimento de Ana Rosa e Wilson Silva, Figueiredo (2017, p. 125) diz: "[o] casal foi preso pelo delegado Sérgio Fleury, em 22 de abril de 1974, e levado para a Casa da Morte, em Petrópolis, onde foi torturado e executado". Ambos tinham 32 anos quando desapareceram. O episódio envolvendo o sumiço e a morte de Ana Rosa e Wilson Silva também se encontra registrado no Dossiê dos mortos e desaparecidos políticos a partir de $1964^{3}$, no qual consta o depoimento de Bernardo Kucinski:

\begin{abstract}
Minha irmã, Ana Rosa Kucinski, e meu cunhado, Wilson Silva, foram presos e desaparecidos em São Paulo, na tarde de 22 de abril de 1974. Nesse dia, Wilson Silva e seu colega de trabalho Osmar Miranda Dias foram fazer um trabalho de rotina, saindo do escritório da Av. Paulista para o centro da cidade, um pouco antes da hora do almoço, após o que Wilson se separou de Osmar dizendo que iria se encontrar com sua esposa Ana Rosa, na Praça da República. A partir desta tarde, nunca mais foram vistos. (DMDP, 1995, p. 256)
\end{abstract}

Por meio de colegas de trabalho, a família foi informada sobre a ausência de Ana Rosa na universidade ${ }^{4}$. De imediato, seus familiares adotaram medidas a fim de descobrir o paradeiro do casal, dentre as quais, a impetração de vários habeas corpus na tentativa de localizar Ana Rosa e Wilson Silva; porém, "todos eles prejudicados pela resposta de que nenhum dos dois se encontrava preso" (DMDP, 1995, p. 256). Na data de 10 de dezembro de 1974, um pedido de investigação foi enviado à Comissão de Direitos Humanos da OEA. Sobre a solicitação, Kucinski afirma: "Meses depois, a família recebeu resposta da OEA, onde esta afirmava que, consultado, o Governo Brasileiro declinava qualquer responsabilidade no episódio" (DMDP, 1995, p. 257). Ainda em dezembro de 1974, o general Golbery do Couto e Silva chegou a reconhecer que Ana Rosa estava presa em uma instituição da Aeronáutica. Kucinski conta também que o governo dos EUA, por intermédio do Departamento de Estado, informou-lhes que Ana Rosa ainda se encontrava viva, em local não sabido. Quanto a Wilson Silva, o governo americano afirmou que o jovem militante estaria provavelmente morto.

Além disso, por meio de uma audiência realizada a pedido do cardeal arcebispo de São Paulo, Dom Paulo Evaristo Arns, familiares de desaparecidos políticos tiveram um encontro

\footnotetext{
${ }^{2}$ Nota de rodapé em Gaspari (2014, p. 389): "Depoimento do general Dale Coutinho dos Santos Araújo, em Percival de Souza, Autópsia do medo, pp. 12-3".

${ }^{3}$ Doravante, denominado apenas pela sigla DMDP.

${ }^{4}$ Como desdobramento, Ana Rosa foi demitida pela Congregação do Instituto de Química (IQ) da Universidade de São Paulo (USP) em 23 de outubro de 1975 por "abandono de função".
} 
com o general Golbery do Couto e Silva em Brasília. Dias após esse episódio, o Ministro da Justiça à época, Armando Falcão, publicou uma nota oficial na qual informava sobre "desaparecidos políticos". Sobre Ana Rosa e Wilson Silva, "a nota do Ministério alegava que eram 'terroristas' e estavam 'foragidos"” (DMDP, 1995, p. 257). Em pesquisas realizadas pelos familiares nos arquivos do antigo DOPS/SP, foi localizada uma ficha sobre Ana Rosa contendo a seguinte informação: "presa no dia 22 de abril de 1974 em SP” (DMDP, 1995, p. 256). Já o documento sobre Wilson Silva no DOPS/SP constava: "preso em 22 de abril de 1974, em São Paulo, junto com sua esposa Rosa Kucinski” (DMDP, 1995, p. 403). Em 1993, o relatório do Ministério da Marinha, enviado ao Ministro da Justiça, Maurício Correa, confirmou a informação de que Wilson Silva havia sido “preso em São Paulo a 22 de abril de 1974, e dado como desaparecido desde então" (DMDP, 1995, p. 403).

Em entrevista concedida anos mais tarde, publicada na obra Direito à memória e à verdade, o tenente-médico Amílcar Lobo, que atuou no DOI-CODI e na "Casa da Morte, denunciou os assassinatos políticos que testemunhou durante sua passagem por aquelas unidades militares. Sobre o caso do desaparecimento de Ana Rosa e Wilson Silva, ele disse:

Procurado por Bernardo Kucinski, o médico reconheceu Wilson Silva como sendo uma das vítimas de torturas atendidas por ele. Ao ver a foto de Ana Rosa, o militar a identificou como uma das presas, mas sem demonstrar convicção ou certeza. Também o ex-agente do DOI-CODI/SP, em entrevista à Veja de 18/11/1992, informou: "Foi o caso também de Ana Rosa Kucinski e seu marido, Wilson Silva. Foram delatados por um cachorro, presos em São Paulo e levados para a casa de Petrópolis. Acredito que seus corpos também foram despedaçados”. (BRASIL, 2007, p. 391 e 382)

Outro importante relato é o do ex-delegado do DOPS/ES, Cláudio Guerra. Ele confirmou sua participação no transporte dos corpos do casal, levados para serem incinerados na Usina Cambahyba, no Rio de Janeiro. Como explicam Marcelo Netto e Rogério Medeiros (2012, p. 25), “[a]o lado do delegado paulista Sérgio Paranhos Fleury, o também delegado capixaba Cláudio Antonio Guerra se sobressaiu nas execuções de adversários do regime militar". Em um trecho do depoimento dado a Netto e Medeiros (2012, p. 55), Guerra revelou:

Eu me lembro muito bem de um casal, Ana Rosa Kucinski da Silva e Wilson Silva, por conta de um incidente no caminho entre a rua Barão de Mesquita e a usina.

Eu e o sargento Levy, do DOI, fomos levar seus corpos. Os dois estavam completamente nus. A mulher apresentava muitas marcas de mordidas pelo corpo, talvez por ter sido violentada sexualmente. O jovem não tinha as unhas da mão direta. Tudo levava a crer que tinham sido torturados. Não havia perfuração de bala neles. Quem morre de tiro não sofre. Morte por tortura é muito mais desumano.

Já em 2014, em depoimento à Comissão Nacional da Verdade, o ex-delegado do DOPS novamente fez referência ao caso. Ele disse que Ana Rosa "teria sido torturada brutalmente no 
centro clandestino de Petrópolis conhecido por Casa da Morte, inclusive sexualmente" (CNV, 2014, v. 1, p. 344). E acrescentou: "Ela estava em Petrópolis e ela foi muito torturada. Ela estava visivelmente violentada. Com os órgãos genitais cheios de sangue e a roupa toda cheia de sangue" (CNV, 2014, v. 1, p. 344). Conforme também o depoimento do ex-sargento do Exército Marival Chaves do Canto, Ana Rosa e Wilson Silva foram pegos devido à atuação de um agente infiltrado na ALN. Em depoimento à Comissão Externa para os Mortos e Desaparecidos Políticos da Câmara dos Deputados, Canto (apud MIRANDA; TIBÚRCIO, 2008, p. 182) disse: "foi por causa do trabalho de Jota, João Henrique Ferreira Carvalho, que Wilson Silva e sua mulher Ana Rosa Kucinski Silva foram presos, torturados e mortos”. O ex-sargento também relatou sobre o envolvimento do coronel Freddie Perdigão no caso: "desde sua época de capitão, [Perdigão] tinha influência suficiente no porão para viver levando presos de São Paulo para Petrópolis. Ele participou do desaparecimento de Ana Rosa Kucinski Silva e Wilson Silva".

Em 1995, a Lei No 9.140 reconheceu a responsabilidade do Estado em decorrência do desaparecimento de pessoas envolvidas, ou acusadas de envolvimento, em atividades políticas entre 02 de setembro de 1961 e 05 de outubro de 1988. No Anexo I da referida Lei, foram inseridos os nomes de 136 pessoas desaparecidas - e, portanto, reconhecidas oficialmente como mortas - com a informação da época de seu desaparecimento. Dentre elas constam os nomes de Ana Rosa Kucinski Silva e Wilson Silva, desaparecidos em 1974.

\section{Um retrato da ditadura em $K$. Relato de uma busca}

O escritor Bernardo Kucinski atuou como militante durante a ditadura, tendo sido preso e, também, obrigado a se exiliar. Porém, pesa-lhe a experiência do desaparecimento da irmã e do cunhado no início da década de 1970, uma situação até hoje não elucidada por completo. "Todo o resto", diz Kucinski, "em especial a censura nos jornais alternativos em que trabalhei, o exílio voluntário de quatro anos, foram meros percalços, frente à tragédia que se abateu sobre minha família"5 (KUCINSKI, 2014b, não p.). A narração dessa experiência traumática só pôde ocorrer após um longo distanciamento no tempo e pela via ficcional, com o lançamento de $K$. Relato de uma busca em 2011. Aclamado pela crítica, foi finalista dos prêmios literários São Paulo de Literatura, União Brasileira de Escritores e Portugal Telecom em 2012

\footnotetext{
${ }^{5}$ Entrevista a Rogério Pereira, intitulada A libertação de Kucinski. Disponível em: <http://rascunho.com.br/alibertacao-de-kucinski/>. Acesso em: 20 fev. 2018.
} 
(FIGUEIREDO, 2017, p. 126). Além do sucesso em âmbito nacional, K. Relato de uma busca foi traduzido para diversas línguas.

Com o subtítulo Relato de uma busca, a narrativa aborda a história de um pai idoso, identificado apenas pela letra "K", à procura da filha desaparecida em plena ditadura brasileira na década de 1970. O romance é composto por 29 capítulos-fragmentos. Cada capítulo possui independência, mas a leitura em conjunto revela detalhes e elos importantes para a compreensão dos acontecimentos narrados. A estrutura em capítulos fragmentados privilegia a utilização de uma diversidade de vozes narrativas, caracterizando o seu aspecto polifônico. Deste modo, além da voz que conduz a história de K., verificam-se outras vozes (em primeira ou terceira pessoa) que surgem como pontos de vista complementares à narrativa do velho pai em busca da filha desaparecida. Outro elemento de destaque refere-se à utilização de gêneros textuais variados, como, por exemplo, os gêneros "carta" e "ata". Essa formatação reforça o aspecto fragmentário e não linear da narrativa que se apresenta como uma história a partir de pequenos fragmentos.

Na distribuição dos capítulos, predomina a narração da busca de K. pela filha. Assim, do total, 15 capítulos giram em torno do velho judeu. São eles: "Sorvedouro de pessoas"; "Os informantes"; "Os primeiros óculos"; "O matrimônio clandestino"; "Jacobo, uma aparição"; "Nesse dia, a terra parou"; "A matzeivá"; "Os desamparados"; "Imunidades, um paradoxo"; "Na Baixada Fluminense, pesadelo"; "Um inventário de memórias"; "O abandono da literatura"; "Os extorsionários"; "Os nomes e as ruas" e "No barro branco". Destaca-se ainda que, em alguns capítulos, o emprego da memória surge como recurso de inserção de informações sobre o passado de K. e sua família, revelando, por exemplo, sua vida na Polônia. Outras vozes narrativas surgem intercaladas à história de K. Em "A queda do ponto"; "Carta a uma amiga"; "Livros e expropriação"; e "Mensagem ao companheiro Klemente", o ponto de vista adotado pelo autor privilegia a voz de militantes de organizações de esquerda. Uma das questões abordadas sob essa perspectiva refere-se ao desmantelamento das organizações de esquerda frente ao avanço do aparelho repressivo e a falta de autocrítica por parte de seus líderes. Já em capítulos como "A abertura", “A terapia”, “A cadela” e "O livro da vida militar" têm-se a perspectiva de agentes da repressão ou de civis que, de alguma forma, estiveram a serviço ou ligados a ela ou a seus agentes.

O ponto nerval na obra é a forma como o estado de espírito da personagem central é construído com emoção e precisão milimétrica. Distanciando-se da maioria das obras produzidas sobre a ditadura civil-militar, centradas muitas vezes em experiências 
autobiográficas e sob a ótica da militância que se opôs ao regime militar, o escritor ampara-se em sua própria experiência e direciona seu olhar para aqueles que não foram alvos diretos do aparato repressivo, a saber, os familiares de desaparecidos políticos que, diante da perda de um ente querido, passaram a ter de conviver com o trauma da ausência e da incerteza. Nessa perspectiva, K. Relato de uma busca pode ser compreendido como uma narrativa que expõe o modo como certos "episódios de violência resultam em impacto em outros que tinham conexões afetivas com os que foram agredidos" (GINZBURG, 2012a, p. 7), revelando, assim, a maneira como tais eventos se constituem como traumas históricos, a um só tempo, individuais e coletivos.

O capítulo que dá início a história de K. intitula-se "Sorvedouro de pessoas". O título faz alusão à prática do desaparecimento forçado, método empregado pelo aparato repressivo contra os opositores ao regime militar:

O pavor é muito maior com o desaparecimento do que com a morte. A morte, não, você vê o cadáver do cara, o cara ali, acabou, acabou. Não tem mais... mais o que pensar nele. O meu destino, se eu falhar, vai ser esse. Já quando você desaparece isso é ensinamento estrangeiro - quando você desaparece, você causa um impacto muito mais violento no grupo. Cadê o fulano? Não sei, ninguém viu, ninguém sabe. Como? O cara sumiu como? (CNV, 2014, v. 1, p. 500)

A citação acima foi extraída do Volume I, do Relatório da Comissão Nacional da Verdade. Trata-se de trecho do depoimento do coronel reformado Paulo Malhães — torturador confesso que integrou o CIE —, dado à Comissão Estadual da Verdade do Rio de Janeiro (CEVRio), nos dias 18 de fevereiro e 11 de março de 2014. "Sorvedouro de pessoas" marca o encontro de K. com essa experiência radical, com o desaparecimento da filha envolvida em atividades políticas: “A tragédia já avançara inexorável quando, naquela manhã de domingo, K. sentiu pela primeira vez a angústia que logo o tomaria por completo. Há dez dias a filha não telefona" (KUCINSKI, 2014a, p. 13). A partir daí, sua vida transforma-se e passa a ser tensionada pela oscilação entre expectativas e angústias, produzidas pela paradoxal relação entre ausência e presença, existência e inexistência.

Em outro momento, em sua ânsia pela busca de informações, K. depara-se com uma notícia no Estado de S. Paulo sobre uma reunião com "familiares de desaparecidos políticos", organizada pelo arcebispo de São Paulo, e decide ir até o local. O processo de perda da identidade do velho pai é gradual. Ele, que nunca adentrara em um templo católico, pois desprezava toda e qualquer prática religiosa, resolve comparecer à reunião, mesmo contrariando suas convicções: "naquela tarde, nada disso importava. Uma autoridade importante, um 
arcebispo, ia falar sobre as estranhas desaparições” (KUCINSKI, 2014a, p. 20). Durante a longa conversa, os testemunhos de familiares de desaparecidos políticos dão a dimensão do "sorvedouro de pessoas":

Falava uma senhora de muita idade, talvez passando dos noventa, franzina, miúda, de óculos na ponta do nariz e cabelos brancos; seu marido voltava do exílio por Uruguaiana, chegou até um ponto de encontro pré-combinado, do lado de cá da fronteira, e desapareceu por completo, sem deixar vestígio, como se tivesse evaporado ou anjos o tivessem alçado aos céus. [...] Uma jovem de não mais que vinte anos pediu para falar em nome de um grupo sentado à sua volta, "familiares dos desaparecidos do Araguaia", disse ela. K. pela primeira vez ouvia alguém falar do Araguaia; ficou sabendo que muitos rapazes tinham sido presos pelas Forças Armadas no meio da floresta amazônica e executados lá mesmo. [...] Um rapaz encontrou-se com a esposa no Conjunto Nacional para almoçarem juntos e os dois nunca mais foram vistos. À medida que falava, a mãe do rapaz mostrava aos vizinhos de assento as fotos do filho, da nora e do netinho. Um senhor levantou-se, disse que viera de Goiânia especialmente para a reunião. Seus dois filhos, um de vinte anos e o outro de apenas dezesseis, foram desaparecidos. Esse senhor gaguejava, parecia em estado catatônico. Foi o primeiro a usar a expressão "foram desaparecidos". (KUCINSKI, 2014a, p. 21 22)

Ao contar sua história, cada familiar expõe a forma como seus entes "foram desaparecidos" (KUCINSKI, 2014a, p. 22) pelo regime militar, evidenciando, assim, o modus operandi do aparelhamento repressivo: "todos os vinte e dois casos computados naquela reunião tinham uma característica comum assombrosa: as pessoas desapareciam sem deixar vestígios. Era como se volatilizassem” (KUCINSKI, 2014a, p. 22-23). Narrativas dentro da narrativa, cada relato em "Sorvedouro de pessoas" reverbera a "política do extermínio" dos porões, um dispositivo extremamente articulado que, segundo Elio Gaspari (2014, p. 392), no auge de suas atividades, passou a matar "todo aquele que não convinha deixar vivo".

As engrenagens do dispositivo repressivo que permitiam a eliminação de opositores também são descritas em $K$. Relato de uma busca, por meio da inserção de diferentes personagens. Conforme explica Kucinski (2014c, não p.): "O livro apresenta uma variedade de colaboradores com a repressão, desde agentes diretos, como um torturador, até juízes de tribunais e donos de redes de televisão, passando por informantes e professores da Universidade de São Paulo em estado de desrazão"6. De forma sútil e precisa, o escritor introduz o assunto ainda no capítulo introdutório, quando $\mathrm{K}$. se dirige até a universidade para tentar obter alguma informação com as colegas de Ana Rosa: "Hesitantes, olhavam de soslaio umas para as outras. Depois, como se temessem a indiscrição das paredes, puxaram K. para conversar no jardim.

6 Entrevista a Luciano Gallas, intitulada $K$. em busca da verdade. Disponível em: <http://www.ihuonline.unisinos.br/index.php?option=com_content\&view=article\&id=5411\&secao=439>. Acesso em: 29 maio 2018. 
[...] Falavam aos sussurros, sem completar as frases, como se cada palavra escondesse mil outras de sentidos proibidos" (KUCINSKI, 2014a, p. 15). Elas hesitam, receiam a "indiscrição das paredes", falam sussurradamente, de forma lacunar. Esses gestos revelam o cenário de tensão e medo dentro da universidade. Mas K. não percebe e insiste em querer ouvir alguma informação dos superiores da filha. Imediatamente, ele é aconselhado a recuar, sendo informado da presença de pessoas estranhas no campus: "Desconhecidos andaram perguntando por ela, sabe? Há gente estranha no campus. Anotam chapas de carros. Eles estão dentro da reitoria. Eles quem? Não souberam responder" (KUCINSKI, 2014a, p. 15-16). Desde os instantes iniciais da instalação da ditadura no país, o ambiente universitário gerou inquietação entre os agentes da repressão, com protestos organizados pela juventude estudantil ocorrendo logo após o golpe de 1964. Com uma forte oposição ao regime insurgindo-se de dentro dos espaços estudantis, o aparato repressivo procurou realizar ações eficazes para atuar dentro das instituições de ensino. Assim, em 26 de fevereiro de 1969, foi promulgado o Decreto-Lei $\mathrm{N}^{\circ}$ 477, que estabelecia "infrações disciplinares praticadas por professores, alunos, funcionários ou empregados de estabelecimentos de ensino público ou particulares"7. Com base nesse regulamento, professores, funcionários e alunos podiam ser punidos de forma sumária.

Os mecanismos de repressão empregados pela ditadura são tema de pesquisas que mostram desde variadas formas de tortura física empregadas pelos seus agentes, até o uso de métodos de implantação do terror psicológico extremamente eficazes contra quem buscasse se opor ao governo militar. Sobre isso, os estudos de Caroline Silveira Bauer (2012) revelam algumas das práticas adotadas pela repressão durante a ditadura civil-militar. A autora observa que estratégias de disseminação do medo, como modo de dominação política, são baseadas em "métodos de terror físico, ideológico e psicológico, assimilados de outras experiências e do desenvolvimento de doutrinas regionais próprias". Embora variassem de intensidade e de extensão, possuíam um “núcleo comum” (BAUER, 2012, p. 29) que tem como característica

[a] produção de informações a partir da "lógica de suspeição"; pelo sequestro como forma de detenção; pela realização do interrogatório e da tradição inquisitorial das práticas policiais; pela presença das torturas físicas e psicológicas; pela censura e desinformação; e, principalmente, pela prática de desaparecimento forçado de pessoas, característica específica da repressão desses regimes. (BAUER, 2012, p. 29)

\footnotetext{
7 Disponível em: <http://www.planalto.gov.br/ccivil_03/decreto-lei/1965-1988/Del0477.htm〉. Acesso em: 30 maio 2018.
} 
A tortura como método de disseminação do medo é abordada por Kucinski sob múltiplas perspectivas, como acontece em "A terapia", capítulo que se desenvolve a partir da tensão entre elementos históricos e ficcionais. Deve-se destacar que, ao abordar a temática da tortura em sua obra, Kucinski não recorre a imagens fortes de violência, tal como ocorre em diversas narrativas sobre o período ditatorial, como, por exemplo, na obra Em câmara lenta, de Renato Tapajós. Ao não fazer uso desse expediente, o escritor debruça-se sobre o impacto causado nas pessoas que presenciaram essas cenas de barbárie. "A terapia" centra-se na personagem Jesuína Gonzaga, uma faxineira que trabalhou em um dos centros clandestinos integrados à estrutura da repressão política. Ela é encaminhada para tratamento psicológico, pois sofre de alucinações, insônia e sangramentos. O capítulo se desenvolve a partir do diálogo entre a jovem e uma psicóloga. Jesuína conta que foi "tirada" da penitenciária feminina de Taubaté pelo delegado Fleury para trabalhar em uma casa localizada na cidade de Petrópolis. Questionada sobre o local, a faxineira revela o modo de funcionamento da casa - seu sistema de cárcere, tortura e desaparição:

\begin{abstract}
Quando os carros chegavam, o portão abria, automático, os carros entravam com o preso e logo levavam ele para baixo, onde estavam as celas. Eram só duas celas. [...] Lá no andar de baixo, além das celas, também tinha uma parte fechada, onde interrogavam os presos, era coisa ruim os gritos, até hoje escuto os gritos, tem muito grito nos meus pesadelos. [...] Os presos eram levados para lá, sempre um de cada vez, e nunca mais eu via eles. Lá em cima eu via pela janela eles serem levados para dentro da tal garagem, nunca vi nenhum deles sair. [...] O Fleury já tinha voltado para São Paulo de madrugada. Eu sozinha tomando conta. Então desci até lá embaixo, fui ver. A garagem não tinha janela, e a porta estava trancada com chave e cadeado. Uma porta de madeira. Mas eu olhei por um buraco que eles tinham feito para passar a mangueira de água. Vi uns ganchos de pendurar carne igual nos açougues, vi uma mesa grande e facas igual de açougueiro, serrotes, martelo. É com isso que tenho pesadelos, vejo esse buraco, pedaços de gente. Braços, pernas cortadas. Sangue, muito sangue. (KUCINSKI, 2014a, p. 127, 131-132)
\end{abstract}

Esse capítulo explora um dos locais famigerados que fora utilizado pelo aparato repressivo: a "Casa da Morte", designação pela qual ficou popularmente conhecido o imóvel localizado na Rua Arthur Barbosa, $n^{\circ}$ 668, em Petrópolis, Rio de Janeiro. O local foi um dos principais centros clandestinos de detenção ilegal, tortura, execução e desaparecimento forçado de presos políticos. A casa de Petrópolis era mantida pelo CIE. Sobre ele, consta no relatório da CNV: "Nesse centro, o CIE atuava em coordenação com os DOI-CODI, retirando presos de suas dependências, alguns de outros estados, e levando para Petrópolis. Os destinos de vários desaparecidos políticos estão ligados a esse centro clandestino do CIE” (CNV, 2014, v. 1, p. 158). Sobre a "Casa da Morte", Lucas Figueiredo assevera: "Dos presos que ali entraram, só uma saiu com vida, mesmo assim desfigurada física e psicologicamente: Inês Etienne Romeu, 
a Alda, da VRP" (FIGUEIREDO, 2015, p. 36). Foi por intermédio do depoimento Inês que importantes informações sobre a "Casa da Morte" vieram a público, as quais "são complementadas e corroboradas por documentos produzidas pelo próprio Estado, bem como por testemunhos de ex-presos políticos e depoimentos de agentes da repressão" (CNV, 2014, v. 1, p. 532).

Já em "A Matzeivá”, Kucinski retrata um dos mais terríveis efeitos produzidos pela política de extermínio da ditadura — "a morte da própria morte” (BAUER, 2012, p. 30). O capítulo expõe a dor e o sofrimento de K. por "não conseguir nem ao menos uma inscrição simbólica de sua existência"8 (KEHL, 2011, não p.). Nessa perspectiva, diz a voz narrativa:

K. sente com intensidade insólita a justeza desse preceito, a urgência em erguer para a família uma lápide, ao se completar um ano da sua perda. A falta da lápide equivale a dizer que ela não existiu e isso não era verdade: ela existiu, tornou-se adulta, desenvolveu uma personalidade, criou o seu mundo, formou-se na universidade, casou-se. Sofre a falta dessa lápide como um desastre a mais, uma punição adicional por seu alheamento diante do que estava acontecendo com a filha bem debaixo de seus olhos. (KUCINSKI, 2014a, p. 78-79)

Perpetuando sua dor, outros elementos tornam a expiação de K. ainda mais intensa, como, por exemplo, a suspensão da ordem natural da vida: "não é certo, os filhos é que deveriam enterrar os pais e não os pais enterrarem os filhos, pior que nem isso, nem enterrar podemos" (KUCINSKI, 2014a, p. 87). Ou, então, o fato de a própria sociedade não reconhecer os crimes praticados pelo Estado e, por conseguinte, ignorar o sofrimento vivido pelos familiares dos presos desaparecidos, como pode ser visto na seguinte passagem: "mas ela era terrorista, não era? E você quer que a nossa comunidade honre uma terrorista no campo sagrado, que seja posta em risco, por causa de uma terrorista? Ela não era comunista?” (KUCINSKI, 2014a, p. 81). Essa questão também surge no capítulo "Os desamparados": “daí por diante foi só desinquietação, mudou até o modo da vizinhança, olhando a gente de lado, com desestima, aqui todo mundo se conhece, correu de boca em boca; minha filha quase perdeu o emprego na Prefeitura" (KUCINSKI, 2014a, p. 86-87).

Por outro lado, a situação descrita em "A Matzeivá" contrasta com a narrada em "As ruas e os nomes", que aborda a importância de se manter viva a lembrança dos que lutaram pela restauração da democracia para as gerações seguintes. Além disso, o capítulo expõe o escárnio do Estado brasileiro em face dos crimes cometidos por seus agentes, os quais, ironicamente,

\footnotetext{
${ }^{8}$ Artigo publicado no blog da Boitempo, intitulado Comentários sobre K., de Bernardo Kucinski. Disponível em: <https://blogdaboitempo.com.br/2011/11/28/comentarios-sobre-k-de-bernardo-kucinski/>. Acesso em: 23 abr. 2018 .
} 
acabaram sendo homenageados pelos atos de barbárie que praticaram. Em um dos últimos momentos em que o leitor acompanha o martírio de K., já bastante abatido e transformado, é narrada a visita de familiares de desaparecidos a um loteamento na cidade do Rio de Janeiro. Por meio de "um projeto de lei de um vereador de esquerda" (KUCINSKI, 2014a, p. 160), cada rua do loteamento recebera o nome de desaparecidos políticos, num total de 47 desaparecidos políticos:

O loteamento ficava num fim de mundo, terrenos baratos para estimular a autoconstrução de modo a valorizar terras do mesmo dono mais próximas ao centro, depois de os moradores conseguirem água, luz e ônibus. [...] O próprio vereador espetou estacas nas interseções principais das ruas ainda mal demarcadas e nelas pregou as placas azuladas com os nomes dos desaparecidos políticos. Só os nomes, sem indicação de data de nascimento, nem, obviamente, de morte. [...] Os familiares, não mais que quinze, a maioria de São Paulo, reuniram-se defronte ao Hotel Glória, de onde seguiram por micro-ônibus até o loteamento do outro lado da ponte RioNiterói. Foi uma viagem demorada. Embora exausto, cansado de tudo, até de viver, K. decidira participar da homenagem à filha e ao genro. (KUCINSKI, 2014a, p. 160161)

O discurso proferido pelo vereador durante a pequena cerimônia realizada na chegada ao loteamento ressaltava a "função pedagógica de lembrar às futuras gerações a importância da democracia e dos direitos humanos" (KUCINSKI, 2014a, p. 161). Ao ouvir as palavras do político, K. procura dar um sentido positivo à homenagem, sem, contudo, perder de vista a tragicidade de tantas vidas suprimidas de forma abrupta: "Foi uma fala bonita, pensou K.; discurso e placas procurando atribuir ao desperdício de tantas vidas um significado posterior" (KUCINSKI, 2014a, p. 161).

Outro importante elemento narrativo refere-se à inserção do ponto de vista dos agentes da repressão. A exemplo disto, no capítulo "A abertura", é a voz de Fleury que emerge a partir de diálogos que o delegado tem com seus subordinados e "colaboradores". O capítulo tem como pano de fundo o processo de abertura política instaurado pelo governo Geisel (1974-1979):

Esses filhos da puta pensam que eu tenho medo de figurão. Não tenho medo de figurão porra nenhuma. Pode ser esse canalha do Golbery que agora quer dar uma de bacana, pode ser o presidente da República, pode ser o papa, pode ser esse senador americano de merda, eu estou é cagando para eles todos. Me deram carta branca, que era para acabar com os comunistas, não deram? Acabei com eles, não acabei? Então que não encham o saco. (KUCINSKI, 2014a, p. 69)

Sentindo-se acuado, Fleury manifesta seu descontentamento com o projeto de Geisel: "E os filhos da puta lá em cima falando em abertura. Isso é hora de falar em abertura?" (KUCINSKI, 2014a, p. 73). Ressalta-se que a menção de Fleury ao presidente da República e 
ao General Golbery do Couto e Silva, "principal colaborador de Geisel no processo de abertura política" (GASPARI, 2014, p. 25), é, de fato, historicamente justificada.

Além do processo de abertura, o delegado do DOPS/SP também critica os familiares de desaparecidos políticos que começam a se articular de forma mais efetiva na busca por informações: "O inimigo agora são as famílias desses terroristas. Mas temos que usar mais a cabeça, a psicologia, Mineirinho. Temos que desmontar esses familiares pela psicologia" (KUCINSKI, 2014a, p. 73). A maneira encontrada pelo delegado para "combater" os familiares baseia-se em uma guerra psicológica levada ao extremo. Descobre-se, nesse contexto, que Fleury é a pessoa que articula a "rede sórdida" (KUCINSKI, 2014a, p. 35) por detrás do teatro criado para torturar psicologicamente o velho pai:

Fogaça, senta aí. Senta aí, porra. Escuta bem - tá tremendo por quê? Para de tremer, porra. Você vai fazer um servicinho. Se fizer direito, te solto. Entendeu? Você vai pegar esse telefone que está aí e eu vou te dar um número, vai atender um filho da puta dum velho e você vai dizer a ele o teu nome, [...] diz que você acaba de ser solto do DOPS e que viu a filha dele aqui. O velho vai ficar doidão, vai dar um pulo, fazer um monte de perguntas, como está a filha, você não fala nada, só diz que viu ela, que ela que deu o telefone. [...] O velho não veio porque acreditou, Mineirinho. Esse velho é esperto. Ele veio porque tinha que vir. Ele tinha que vir, entendeu? Mineirinho, aí é que está o truque, a psicologia. Ele tinha que vir, mesmo não acreditando. E sabe por quê? Porque se ele está correndo atrás desses figurões, mesmo depois desse tempo todo, é porque não quer aceitar que a filha já era. Se recusa. Daí se agarra em qualquer coisa, mesmo sabendo que é armação. [...] Vamos quebrar a espinha desse velho. Vamos dar uma canseira nele, uma canseira de matar, até ele ter um infarto, filho da puta. [...] Temos que fazer o contrário; podemos dar a mesma canseira, desmoralizar os porras do mesmo jeito e até pior, espalhando que os corpos estão enterrados cada vez em outro lugar. Procurar para salvar alguém que inda pode estar vivo é uma coisa, mas procurar um corpo, só para poder enterrar, é diferente. (KUCINSKI, 2014, p. 7075)

Ao revelar que Fleury é o responsável por plantar as falsas informações que chegam até K., Kucinski estabelece um novo ponto de vista quanto às situações narradas a partir da ótica do narrador que acompanha a sua trajetória, amarrando, dessa forma, os fios que tecem a trama narrativa. Observe-se os dois trechos destacados abaixo:

Dois dias depois, o sujeito da galeria telefona. Para se identificar menciona o passeio na José Paulino. Diz a K. que sua filha está em Portugal, para onde fugiu há mais de um mês. E desliga. [...] Na semana seguinte chega à loja pelo correio um pacote cilíndrico de Portugal endereçado a K. com o nome da filha como remetente, escrito a mão. Contém cartazes políticos da Revolução dos Cravos. Não é a escrita da filha, ele logo vê. A letra da filha é ligeiramente inclinada para a direita e uniforme, de traços elegantes, como num exercício de caligrafia. Montaram uma farsa. Um teatro para me torturar. Estão todos mancomunados, esses informantes. É uma rede sórdida, que vão todos para o inferno, pragueja em iídiche. (KUCINSKI, 2014a, p. 35).

É do consulado? Me chamem o Rocha, por favor, digam que é o Fleury.

E aí, Rocha? Tudo bem? Preciso que você faça o seguinte. Pegue aí uns folhetos desses capitães aí da tal Revolução dos Cravos, dessa palhaçada, e mande pelo correio para o endereço que o Mineirinho vai te passar. Faça um pacote e mande, via aérea, 
não escreva nada. Só o endereço e o remetente. O remetente você vai escrever à mão, como se fosse de uma moça. (KUCINSKI, 2014a, p. 71)

Extraído do capítulo "Os informantes", o primeiro excerto apresenta um agente que, a mando de Fleury, telefona para K. para avisar que sua filha vive em Portugal há mais de um mês. Uma semana após esse telefonema, o velho recebe um pacote vindo de lá, contendo panfletos da Revolução dos Cravos, como se tivesse sido enviado pela filha; todavia, K. percebe imediatamente que se trata de uma farsa. Já o segundo trecho descreve o diálogo de Fleury com Rocha, no qual o delegado ordena-lhe que envie o pacote de Portugal para o Brasil com panfletos da Revolução de Cravos. Os dois trechos ilustram a forma como Kucinski articula perspectivas e temporalidades que coexistem simultaneamente na narrativa. Essa construção em mosaico possibilita que o leitor tenha um olhar múltiplo sobre os acontecimentos e uma percepção mais abrangente da totalidade.

Outro elemento bastante recorrente na narrativa diz respeito à constante irrupção de um sentimento de culpa em K. Sobre isso ${ }^{9}$, Kucinski admite que a culpabilização da personagem foi um dos elementos centrais na concepção de $K$. Relato de uma busca, aliás, culpa esta que o escritor também assume para si: "A culpa, creio, é o âmago do livro, talvez o motivo que me levou a escrevê-lo e a razão de ter assumido a forma de uma catarse. Não só as pequenas culpas de K. por não perceber o que vinha acontecendo, mas também as minhas” (KUCINSKI, 2013, não p.). Assim, capítulo a capítulo, K. é levado a lidar com o sumiço inesperado da filha e a falta de notícias sobre seu paradeiro. Com o passar do tempo, o enorme cansaço e o arrefecimento de suas esperanças despertam em K. o sentimento de perda e sua busca passa a ser não mais pela filha, mas "para medir a sua própria culpa" (KUCINSKI, 2014a, p. 91): culpa pela "ausência de ritos da família" (KUCINSKI, 2014a, p. 13); pelo "segundo casamento com aquela alemã que a filha detestava", ou devido "à sua devoção tão intensa à língua iídiche" (KUCINSKI, 2014a, p. 45); enfim:

A culpa. Sempre a culpa. A culpa de não ter percebido o medo em certo olhar. De ter agido de uma forma e não de outra. De não ter feito mais. A culpa de ter herdado sozinho os parcos bens do espólio dos pais, de ter ficado com os livros que eram do outro. De ter recebido a miserável indenização do Governo, mesmo sem a ter pedido. No fundo a culpa de ter sobrevivido. (KUCINSKI, 2014a, p. 167)

\footnotetext{
${ }^{9}$ Entrevista ao portal DW Brasil, intitulada Bernardo Kucinski e a culpa dos que sobreviveram. Disponível em: <http://www.dw.com/pt-br/bernardo-kucinski-e-a-culpa-dos-que-sobreviveram/a-17131513 >. Acesso em: 20 maio 2018.
} 
Buscando aprofundar suas considerações, o narrador vale-se das reflexões de Milan Kundera sobre a culpabilização na obra de Kafka, a qual seria inspirada em sua "experiência familiar, no medo que tinha de ser julgado pelo seu pai" (KUCINSKI, 2014a, p. 168). Ao analisar a obra do autor tcheco, Kundera nomeia de "'totalitarismo familiar” o conjunto de mecanismo de culpabilização desvendados por Kafka” (KUCINSKI, 2014a, p. 168). Ao cotejar a realidade kafkaniana com a dos sobreviventes da ditadura civil-militar, a voz narrativa constata: "Nós poderíamos chamar o nosso de "totalitarismo institucional" (KUCINSKI, 2014a, p. 168), compreendendo a forma como o Estado gerenciou o processo para que a culpa incidisse apenas sobre os familiares das vítimas da repressão, tornando, assim, impossível a realização do trabalho de luto e a superação da perda. Dessa forma, diz o narrador: "Porque é óbvio que o esclarecimento dos sequestros e execuções, de como e quando se deu cada crime, acabaria com a maior parte daquelas áreas sombrias que fazem crer que, se tivéssemos agido diferente do que agimos, a tragédia seria abortada" (KUCINSKI, 2014a, p. 168). Um dos imbróglios jurídicos propostos com essa finalidade seriam as "indenizações às famílias de desaparecidos", uma maneira de sepultamento dos casos sem "enterrar os mortos, sem abrir espaço para uma investigação", tornando, assim, "cada família cúmplice involuntária de uma determinada forma de lidar com a história" (KUCINSKI, 2014a, p. 168). Nessa perspectiva, sintetiza o narrador:

O "totalitarismo institucional" exige que a culpa, alimentada pela dúvida e opacidade dos segredos, e reforçada pelo recebimento das indenizações, permaneça dentro de cada sobrevivente como drama pessoal e familiar e não como a tragédia coletiva que foi e continua sendo, meio século depois. (KUCINSKI, 2014a, p. 169)

Essa questão também é abordada no prólogo da obra Prova contrária, de Fernando Bonassi. Ao referir-se à Lei 9.140/1995, que reconheceu como mortas as pessoas desaparecidas em razão de participação de atividades política, Bonassi enfatiza que a norma não previu "a investigação das circunstâncias em que ocorreram, nem a identificação dos autores dessas arbitrariedades" (BONASSI, 2003, p. 5 apud FIGUEIREDO, 2017, p. 128). Dessa maneira, conclui Figueiredo (2017, p. 128), “A indenização sem esclarecimento e punição dos responsáveis gera ainda mais mal-estar e culpa”.

\section{Considerações finais}

Neste trabalho, procurou-se analisar a obra K. Relato de uma busca, de Bernardo Kucinski, romance produzido pelo entrecruzamento entre história e ficção, experiência e 
testemunho. Em seu caráter mais individual, pode-se afirmar que a obra é uma tentativa de "perlaboração" do passado traumático, como o próprio autor declara em entrevista. Contudo, deve-se ressaltar seu papel de portador da memória dos anos de chumbo. Nesse viés coletivo, a narrativa descreve a experiência vivida por várias famílias que foram atingidas pela política de extermínio do regime ditatorial. Daí a ressaltar a capacidade da literatura de Kucinski em recriar, a partir de um trauma individual, uma experiência que afetou aqueles que foram atingidos, direta ou indiretamente, pelas arbitrariedades do estado de exceção instaurado após 1964. De fato, ao reelaborar ficcionalmente o episódio do assassinato de sua irmã e de seu cunhado durante a ditadura civil-militar, Kucinski produziu um testemunho fundamental para a compreensão crítica do processo histórico que marcou a sociedade brasileira na segunda metade do século passado.

Do ponto de vista histórico, $K$. Relato de uma busca apresenta uma riqueza de elementos que somente um leitor munido do conteúdo historiográfico acerca do período é capaz de acessála por completo. Fatos, informações, episódios, personalidades reais, tudo é arquitetado de forma minuciosa, a partir de uma perfeita simbiose entre matéria histórica e forma narrativa. É importante frisar que essa sólida composição de referências históricas presente na obra de Kucinski é tecida a partir das estratégias da fragmentação, da não linearidade e da união de múltiplos pontos de vista narrativos adotadas pelo autor. Esses recursos literários possibilitam que variados elementos do período ditatorial sejam incorporados à narrativa, seja por meio de uma voz narrativa em terceira pessoa, seja através da fala de personagens que, de uma forma ou de outra, ligam-se ao aparato repressivo ou a seus agentes. Todavia, deve-se realçar o fato de que $K$. Relato de uma busca permite ao leitor acessar, com intensa emoção, a dor e a agonia vividas pela personagem central, sentimentos demasiadamente humanos que não cabem nos discursos da história. Portanto, a voz narrativa em terceira pessoa que narra, oniscientemente, a marcha lenta e dolorosa de K. em busca da filha desaparecida, é essencial para o desnudamento dos efeitos da máquina da repressão na vida daqueles que foram atingidos por sua implacável engrenagem de aniquilação.

Ademais, se esse tema ainda possui um espaço considerado ínfimo no cenário da Literatura Brasileira, K. Relato de uma busca pode servir de alento para a criação de uma "cultura da memória" ao menos no campo literário, tal como ocorre em outros países da América Latina. Sob essa perspectiva, ressalta-se a importância dessa obra no sentido de se construir uma ponte entre o passado recente do país e as futuras gerações de escritores. Desse 
modo, ao invés de se tornarem cúmplices do processo de apagamento histórico, da imposição de uma amnésia coletiva, os novos autores podem assumir o papel político e ético de portadores da memória do terror implantado pela política dos quartéis. Somente assim, a memória da ditadura civil-militar talvez deixe de ser ambígua e vaga, como já apontado aqui, soterrada por discursos que tentam apagar o rastro da violência deixado pelo Estado brasileiro e seus cúmplices.

\section{Referências}

BAUER, Caroline Silveira. Brasil e Argentina: ditaduras, desaparecimentos e políticas de memória. Porto Alegre: Medianiz, 2012.

BRASIL. Comissão Nacional da Verdade. Relatório / Comissão Nacional da Verdade. Recurso eletrônico. Brasília: CNV, 2014. 976 p. - (Relatório da Comissão Nacional da Verdade; v. 1).

BRASIL. Decreto-Lei $N^{o} 477$, de 23 de fevereiro de 1969. Define infrações disciplinares praticadas por professores, alunos, funcionários ou empregados de estabelecimentos de ensino público ou particulares, e dá outras providências. Disponível em:

http://www.planalto.gov.br/ccivil_03/decreto-lei/1965-1988/Del0477.htm. Acesso em: 30 maio 2018.

BRASIL. Lei $N^{o}$ 9.140, de 04 de dezembro de 1995. Reconhece como mortas pessoas desaparecidas em razão de participação, ou acusação de participação, em atividades políticas, no período de 02 de setembro de 1961 a 15 de agosto de 1979, e dá outras providências. Disponível em: <http://www.planalto.gov.br/ccivil_03/Leis/L9140.htm>. Acesso em: 18 fev. 2018.

BRASIL. Secretaria Especial dos Direitos Humanos. Comissão Especial sobre Mortos e Desaparecidos Políticos. Direito à verdade e à memória: Comissão Especial sobre Mortos e Desaparecidos Políticos. Comissão Especial sobre Mortos e Desaparecidos Políticos. Brasília: Secretaria Especial dos Direitos Humanos, 2007.

DOSSIÊ dos mortos e desaparecidos políticos a partir de 1964 (DMDP). Comissão responsável: Maria do Amparo Almeida Araújo et al. Prefácio de Dom Paulo Evaristo Arns. Apresentação de Miguel Arraes de Alencar. Recife: Companhia Editora de Pernambuco, 1995.

FIGUEIREDO, Eurídice. A literatura como arquivo da ditadura brasileira. Rio de Janeiro: 7Letras, 2017.

FIGUEIREDO, Lucas. Lugar nenhum: militares e civis na ocultação dos documentos da ditadura. São Paulo: Companhia das Letras, 2015. 
GASPARI, Elio. A ditadura envergonhada. 2. ed. Rev. Rio de Janeiro: Intrínseca, 2014.

GINZBURG, Jaime. Crítica em tempos de violência. São Paulo: Editora da Universidade de São Paulo, Fapesp, 2012a.

KEHL, Maria Rita. Comentários sobre K., de Bernardo Kucinski. Blog da Boitempo. 28 nov. 2011. Não paginado. Disponível em: <https://blogdaboitempo.com.br/2011/11/28/comentarios-sobre-k-de-bernardo-kucinski/>. Acesso em: 23 abr. 2018. Não paginado.

KUCINSKI, Bernardo. K. em busca da verdade. $I H U$ - Revista do Instituto Humanitas Unisinos, São Leopoldo, edição 439, 31 mar. 2014c. Entrevista concedida a Luciano Gallas. Não paginado. Disponível em:

http://www.ihuonline.unisinos.br/index.php?option=com_content\&view=article\&id=5411\&se cao=439. Acesso em: 29 maio 2018.

KUCINSKI, Bernardo. A libertação de Kucinski. Jornal Rascunho, [on-line], edição \#168, abr. 2014b. Entrevista concedida a Rogério Pereira. Não paginado. Disponível em: <http://rascunho.com.br/a-libertacao-de-kucinski/>. Acesso em: 20 fev. 2018.

KUCINSKI, Bernardo. K. Relato de uma busca. São Paulo: Cosac Naify, 2014a.

MIRANDA, Nilmário; TIBÚRCIO, Carlos. Dos filhos deste solo: mortos e desaparecidos políticos durante a ditadura militar, a responsabilidade do Estado. $2^{\mathrm{a}}$ ed. Revista e ampliada. São Paulo: Editora Fundação Perseu Abramo/Boitempo Editorial, 2008.

MORAES, Maria Lygia Quartim de. Prefácio. In: SILVA, Mário Augusto Medeiros de. Os escritores da guerrilha urbana: literatura de testemunho, ambivalência e transição política (1977-1984). São Paulo: Annablume, Fapesp, 2008.

NETTO, Marcelo; MEDEIROS, Rogério. Memórias de uma guerra suja: Cláudio Guerra em depoimento a Marcelo Netto e Rogério Medeiros. Rio de Janeiro: Topbooks, 2012.

SELIGMANN-SILVA, Márcio (Org.). História, memória, literatura: o testemunho na era das catástrofes. Campinas, SP: Editora da Unicamp, 2013.

SELIGMANN-SILVA, Márcio. Narrativas contra o silêncio: cinema e ditadura no Brasil. In: SELIGMANN-SILVA, Márcio; GINZBURG, Jaime; HARDMAN, Francisco Foot (Orgs.). Escritas da violência: representações da violência na história e na cultura contemporâneas da América Latina. Vol. II. Rio de Janeiro: 7 Letras, 2012.

SILVA FILHO, José Carlos Moreira da. O anjo da história e a memória das vítimas: o caso da ditadura militar no Brasil. In: RUIZ, Castor M. M. Bartolomé. Justiça e memória: para uma crítica ética da violência. São Leopoldo: Editora Unisinos, 2009. 